\title{
Physico-chemical factors involved in rivers and lagoons invasion by water hyacinth, Côte d'Ivoire
}

\author{
Victor Kouamé KOUAMÉ ${ }^{1 *}$, Ossey Bernard YAPO ${ }^{1}$, Abiba Sanogo TIDOU-BOGA ${ }^{1}$, \\ Véronique MAMBO ${ }^{1}$, Arsène SEKA ${ }^{1}$ and Pascal HOUENOU ${ }^{1}$ \\ ${ }^{1}$ Laboratoire des Sciences de l'Environnement (L.S.E.), UFR-SGE, Université d'Abobo-Adjamé, 02 B.P. 801. \\ Abidjan 02, Côte d'Ivoire, Tel: 0022520304200, Fax: 0022520304256. \\ *Corresponding author, E-mail: kvictor2@yahoo.fr, Tel: 0022507672119.
}

\begin{abstract}
The invasion of freshwaters and coastal ecosystems by Eichhornia crassipes in tropical and subtropical countries causes serious economic and ecological problems. In the present work, the seasonal distribution of Eichhornia crassipes and abiotic factors that control its distribution in rivers and lagoons from Côte d'Ivoire were reported. Our data show that Eichhornia crassipes proliferation in lagoons was more related to freshwater discharges. By contrast, salinity inhibits its proliferation particularly during dry season when the influence of oceanic waters is significant. In rivers, Echhornia crassipes proliferation in rivers was completely different from one river to another. Higher proliferation of Echhornia crassipes in Comoé and Bia rivers was found during the wet season, while in Tanoé river the maximal proliferation was obtained in the dry season. Nutrient concentrations in rivers and lagoons were generally low due to their uptake by these floating macrophytes. The accumulation of phosphorus in leaves, roots and rhizomes of Echhornia crassipes was different depending on aquatic systems. Higher phosphorus conditions (in rivers), Eichhornia crassipes accumulate more phosphorus in the rhizomes than in the other parts. By contrast, in the lower phosphorus conditions (in lagoons), Eichhornia crassipes accumulates more phosphorus in the leaves than in the other parts.
\end{abstract}

(c) 2009 International Formulae Group. All rights reserved.

Key words: Eichhornia crassipes, West Africa, coastal water, abiotic factors.

\section{INTRODUCTION}

Water hyacinth, Eichhornia crassipes (C.Mart.) Solms (1883) is an invasive plant, native of the Amazon basin (Barrett and Forno, 1982). Most of the problems associated with $E$. crassipes are due to its rapid growth rate, its ability to successfully compete with other aquatic plants, and its easy proliferation. These characteristics give rise to enormous amounts of biomass that cover the water surface of a great variety of habitats often interfering with the use and management of water resources (Trinidad et al., 2008). In fact, as in the majority of tropical and subtropical zones, climatic conditions allow development of this invasive plant in West African waters. According to Ghabbour et al. (2004) and Center et al. (2005), this invasion of waters by 
Eichhornia crassipes of tropical and subtropical countries involves serious economic and ecological consequences. The main problems are related to its interference with navigation, water flow, and recreational use of aquatic systems, and also of mechanical damage to hydroelectric systems. Moreover, it is responsible of drastic changes in freshwater plant and animal communities and it acts as an agent for serious diseases spread in tropical countries (Trinidad et al., 2008). Because of this, water hyacinth (Eichhornia crassipes) is considered to be one of the most noxious aquatic weeds. However, it is well established that these plants have an important role in the regulation of nutrients in aquatic systems and can particularly remove nutrients from wastewaters (Soltan and Rashed, 2003; Jayaweera and Kasturiarachchi, 2004). They also purified water by retaining particles and absorbing substances, and can be used in agriculture as compost (Polprasert et al., 1994; Woomer et al., 2000) or in domestic as biogas (Kumar, 2005; Jayaweera et al., 2007; Almoustapha et al., 2008). In Côte d'Ivoire, the area covers by these floating macrophytes is significant (Figures 2a, 3b) and during the rainy seasons, they are transported from Rivers into the Lagoons. Thus, during the rainy seasons, they constitute an additional source of organic matter inputs in the Lagoons and can contribute to decrease oxygen concentration in these adjacent systems. Depletion of oxygen in water column can cause great phytoplankton and fish mortality. The aim of this study was to measure some physico-chemical components (temperature, $\mathrm{pH}$, conductivity, salinity, dissolved oxygen, phosphate-phosphorus, ammonia-nitrogen, nitrate-nitrogen, and nitrite-nitrogen) that could control water hyacinth (Eichhornia crassipes) proliferation in freshwaters and lagoons of Côte d'Ivoire. Similarly, the content of total phosphorus in water hyacinth's organs has been measured to assess the part of this plant that concentrates more phosphorus. Finally, data obtained could help to know the reasons of the temporal and spatial distribution of water hyacinth in freshwaters and lagoons of Côte d'Ivoire.

\section{MATERIALS AND METHODS \\ Description of study area}

The area of this study is located in West Africa between $2^{\circ} 9 \mathrm{~W}-5^{\circ} \mathrm{W}$ and $5^{\circ} 12 \mathrm{~N}-5^{\circ} 39 \mathrm{~N}$. It is the coastal ecosystem zone of Côte d'Ivoire which corresponds to a large fraction of the surface area of lagoons in West Africa (Binet et al. 1995). There are three lagoonal systems (Ebrié, Aby, and Grand-Lahou) which gather rivers of the zone along some $300 \mathrm{~km}$ of the coastline (Figure 1). Ebrié lagoon is connected to the Atlantic Ocean through the Vridi canal and is fed by the Comoé, the Agneby and the La Mé rivers. The eastern regions are dominated by continental water flows, the central region is influenced by the Atlantic Ocean and by the discharge of human wastes, while the western regions are relatively isolated from these sources (Dufour, 1982). The water salinity of the Ebrié lagoon is controlled by its exchange with the ocean, freshwater inputs and rainfall. The Aby Lagoon has an area of $424 \mathrm{~km}^{2}$ of which $30 \mathrm{~km}^{2}$ falls within Ghana. It is fed by the Bia and the Tanoé rivers. The GrandLahou Lagoon is fed by the Bandama, the Gô and the Boubo rivers.

The study zone is characterized by a climate dominated by abundant precipitations and two main seasons: dry and wet seasons (Durand and Chantraine, 1982). The dry season (January to April) during which continental water contributions to lagoons are negligible, evaporation is maximal and influence of marine water is dominant. The wet season is characterized by high precipitations (May to December), followed by the provision of lagoons by coastal rivers. This situation leads to a significant fall of the salinity of lagoon (September to December) corresponding to rivers flood season. The 


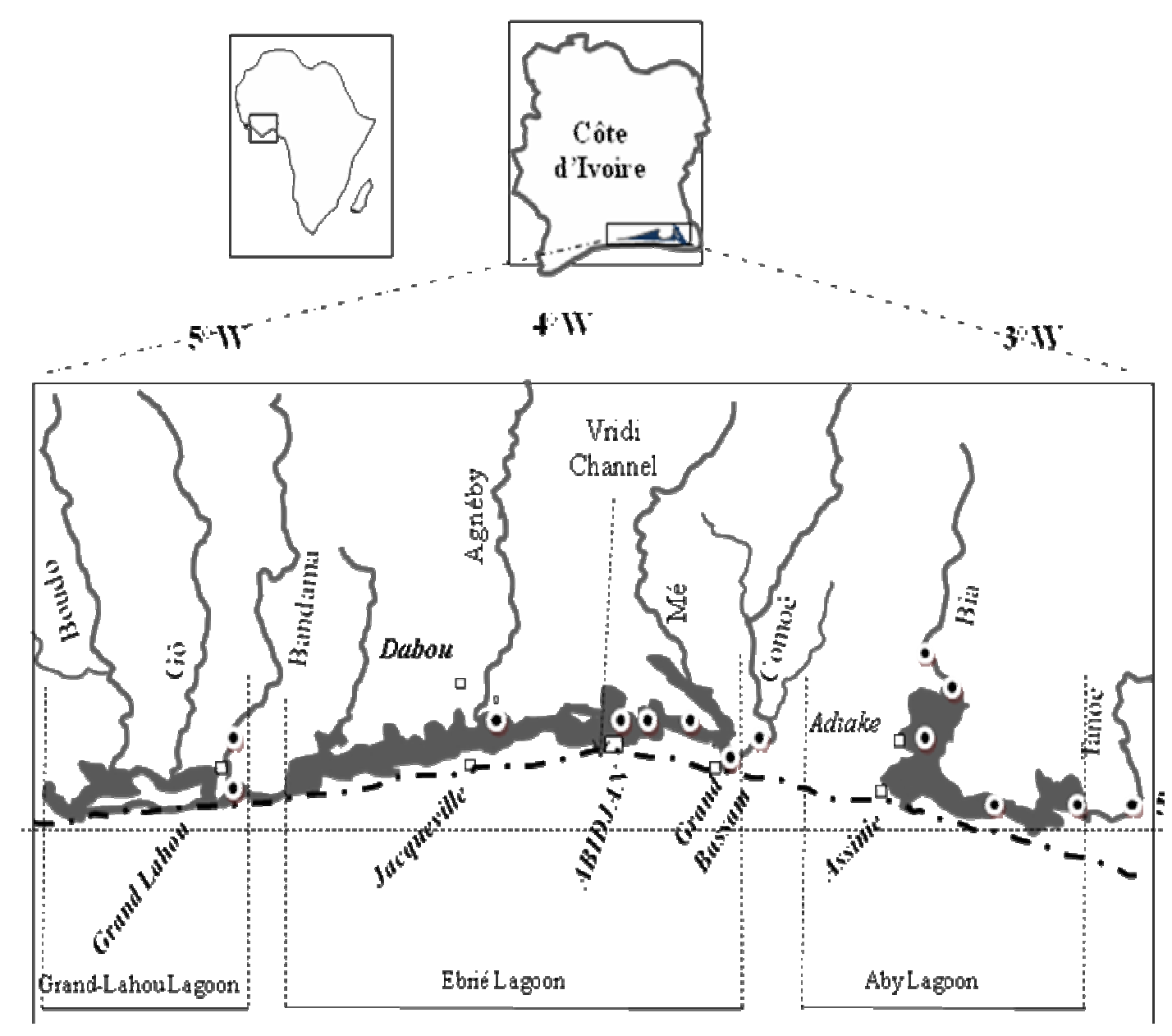

Figure 1: Localization of sampling stations

importance of the hydrographic network and the connections between several rivers in this zone are factors which facilitate the transport of these floating macrophytes into the lagoons during the rainy season.

\section{Sampling and analyses}

Sampling was carried out in two lagoons (Aby and Ebrié) and four rivers (Bia, Tanoé, Comoé and Bandama) during the two seasons in October 2006 for the wet season and in March 2007 for the dry season. 14 stations (Figure 1) were selected according to water hyacinth density during the wet season campaign. The geographical coordinates of these stations were registered using a GPS (MAGELLAN 320). During the dry season, the number of plant samples went down from 14 to 11 because water hyacinth was not present at stations LE2 and LE3 in Abidjan and LE4 in Jacqueville. Water samples for nutrient analyses were collected and saved in polyethylene bottles $(1000 \mathrm{~mL})$ cleaned with acid and rinsed with water. The samples were collected by direct immersion of the bottle into the river or lagoon. Samples were kept cool in thermos with ice and brought back to the laboratory for analysis 
imperatively within 48 hours according to AFNOR standards (AFNOR, 2001). Temperature, $\mathrm{pH}$, conductivity, salinity and dissolved oxygen of water have been measured in situ using two multiple-sondes (WTW 340i and Oxi 340).

For the sampling of Eichhornia crassipes, five plants per station with healthy organs (leaves, roots, rhizomes) were taken, and then rinsed. Samples were taken to the laboratory for their phosphorus content determination.

Total phosphorus measurement was performed according to AFNOR standards (AFNOR, 2001) after a pretreatment of plant samples. Samples of water hyacinth were dried and divided in three parts (roots, leaves, rhizomes). The stem, very short is mixed with the root. Each organ is then crushed, and $100 \mathrm{mg}$ are taken. This sample test is mineralized with sulphuric acid and nitric acid to transform all the phosphorus forms into phosphate-phosphorus.

\section{Statistical analysis}

For statistical analysis, the normality was first verified with a Kolmogorov-Smirnov test and homogeneity of variance tested with the Levene test. Then, ANOVA was performed only to show if there was a difference between means. If yes, Tukey's test was used to identify differences among means. All tests were used with $p<0.05$. The correlation coefficient (r) of Spearman was used for correlation evaluation between total phosphorus content of water hyacinth and water phosphorus concentration. All analyses were performed with STATISTICA 7.1 software (Statsoft, 2005).

\section{RESULTS}

Distribution of water hyacinth in Ebrié Lagoon and Tanoé River

Figures 2 and 3 show spatial and temporal distribution of water hyacinth in Tanoé River and Ebrié Lagoon. During the wet season, Eichhornia crassipes was observed to be very widespread in Tanoé River and in the Ebrié Lagoon. However, the tufts were more important in Ebrié lagoon (Figure 2a) than in Tanoé River (Figure 3a) during this season. In contrast, during the dry season, these plants were absent in Ebrié Lagoon, but well developed in the Tanoé River suggesting that processes that control their dynamics in these two aquatic areas are different.

\section{Physicochemical characteristics of rivers and lagoons}

During both seasons, temperature and $\mathrm{pH}$ values were lower in rivers than in lagoons (Figures 4a, 4b, 5a and 5b) and means values ranged from 26.6 to $30.0{ }^{\circ} \mathrm{C}$ in the rivers and from 29.8 to $30.5^{\circ} \mathrm{C}$ in the lagoons (Tables 1 and 2). $\mathrm{pH}$ values were slightly lower in the rivers than in lagoons. And mean values ranged from 6.5 to 7.9 and from 6.9 to 8.8 in the rivers and lagoons, respectively. Conductivity values were very lower in the rivers (from $4.36 \mu \mathrm{S} / \mathrm{cm}$ to $14160 \mu \mathrm{S} / \mathrm{cm}$ ) than in the lagoons (from $5.02 \mu \mathrm{S} / \mathrm{cm}$ to 42400 $\mu \mathrm{S} / \mathrm{cm}$ ) during the dry season.

Salinity in lagoons shows a seasonal variability due to the changes of freshwater and marine water inputs. The highest values were obtained during the dry season while the lowest were observed during the rainy season due to dilution. Mean salinity values ranged from 7.8 to 12.3 during the rainy and dry seasons, respectively. Although nutrient concentrations in the rivers and lagoons were low, some of them showed a seasonal variability. The patterns of $\mathrm{PO}_{4}-\mathrm{P}$ and $\mathrm{NH}_{4}-\mathrm{N}$ were opposite. The maximum values of $\mathrm{PO}_{4}-\mathrm{P}$ were obtained during the rainy season while those of $\mathrm{NH}_{4}-\mathrm{N}$ were observed during the dry season. Mean $\mathrm{PO}_{4}-\mathrm{P}$ concentrations ranged from $0.42 \mathrm{mg} / \mathrm{L}$ to $0.72 \mathrm{mg} / \mathrm{L}$ in the lagoons and rivers, respectively. Those of $\mathrm{NH}_{4}-\mathrm{N}$ ranged from $0.59 \mathrm{mg} / \mathrm{L}$ to $0.69 \mathrm{mg} / \mathrm{L}$ in the rivers and lagoons, respectively. During both 

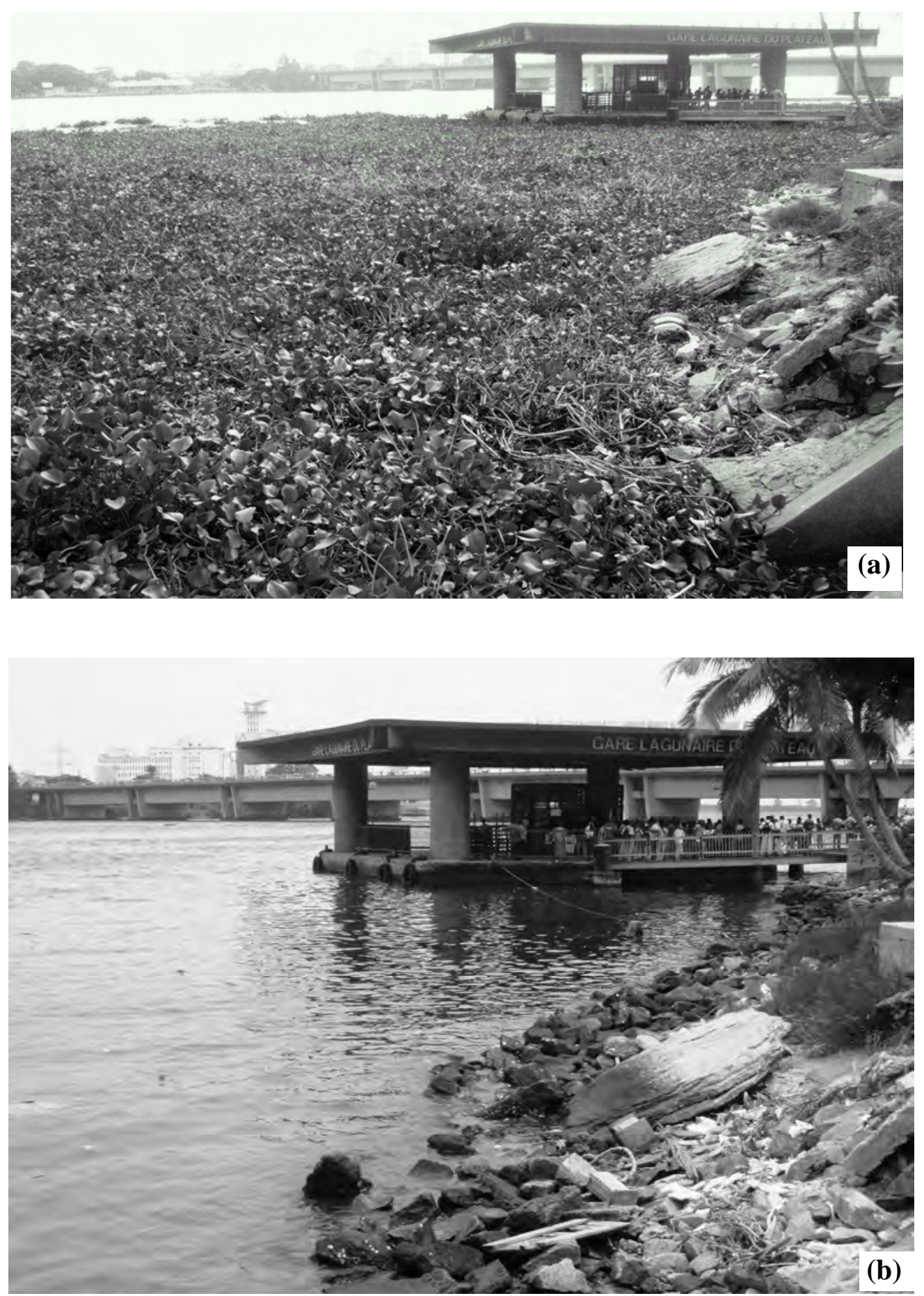

Figure 2: Ebrié Lagoon in Abidjan City: (a) wet season (October 2006); (b) dry season (March 2007) 

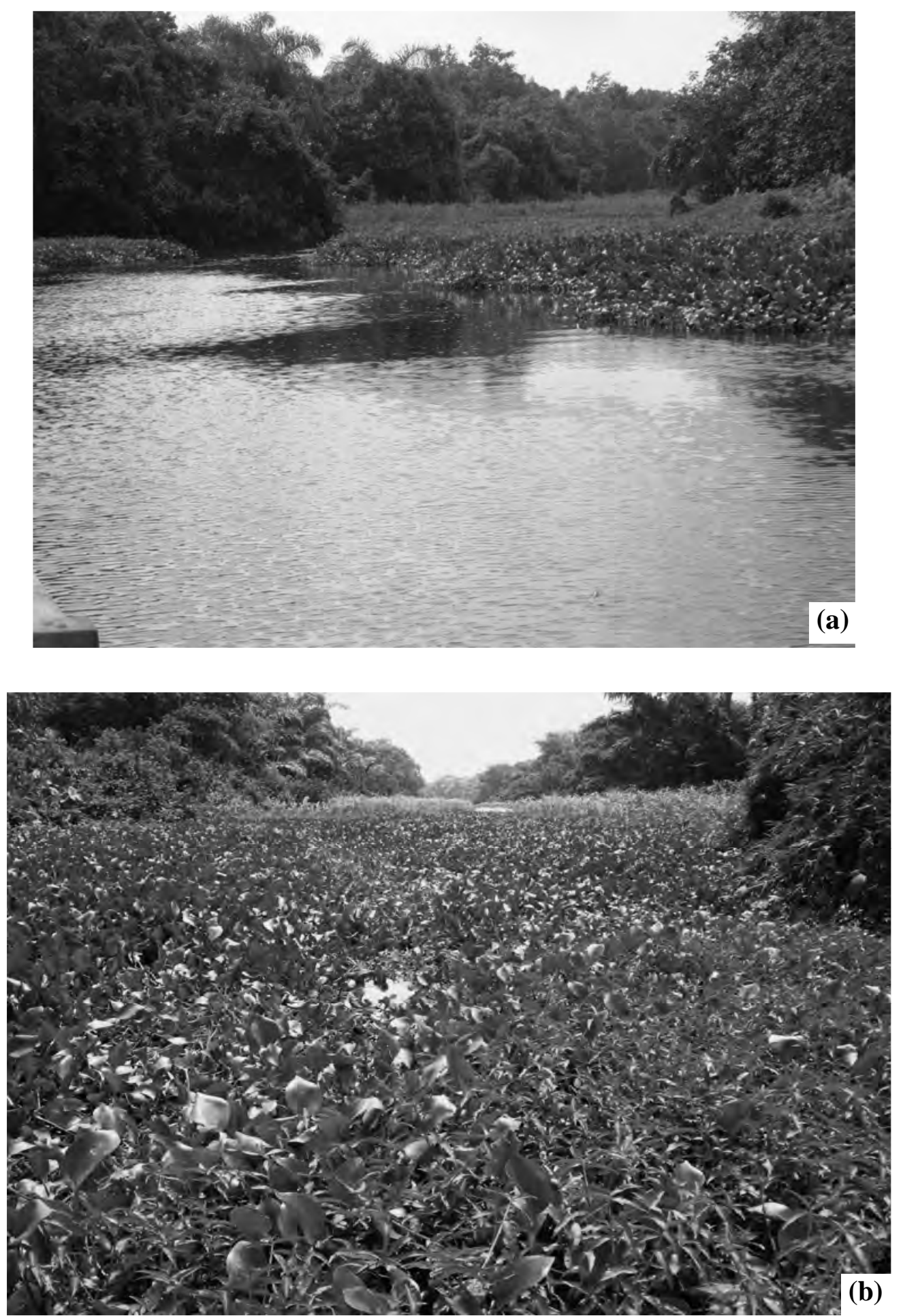

Figure 3: Tanoé River: (a) wet season (October 2006); (b) dry season (March 2007). 

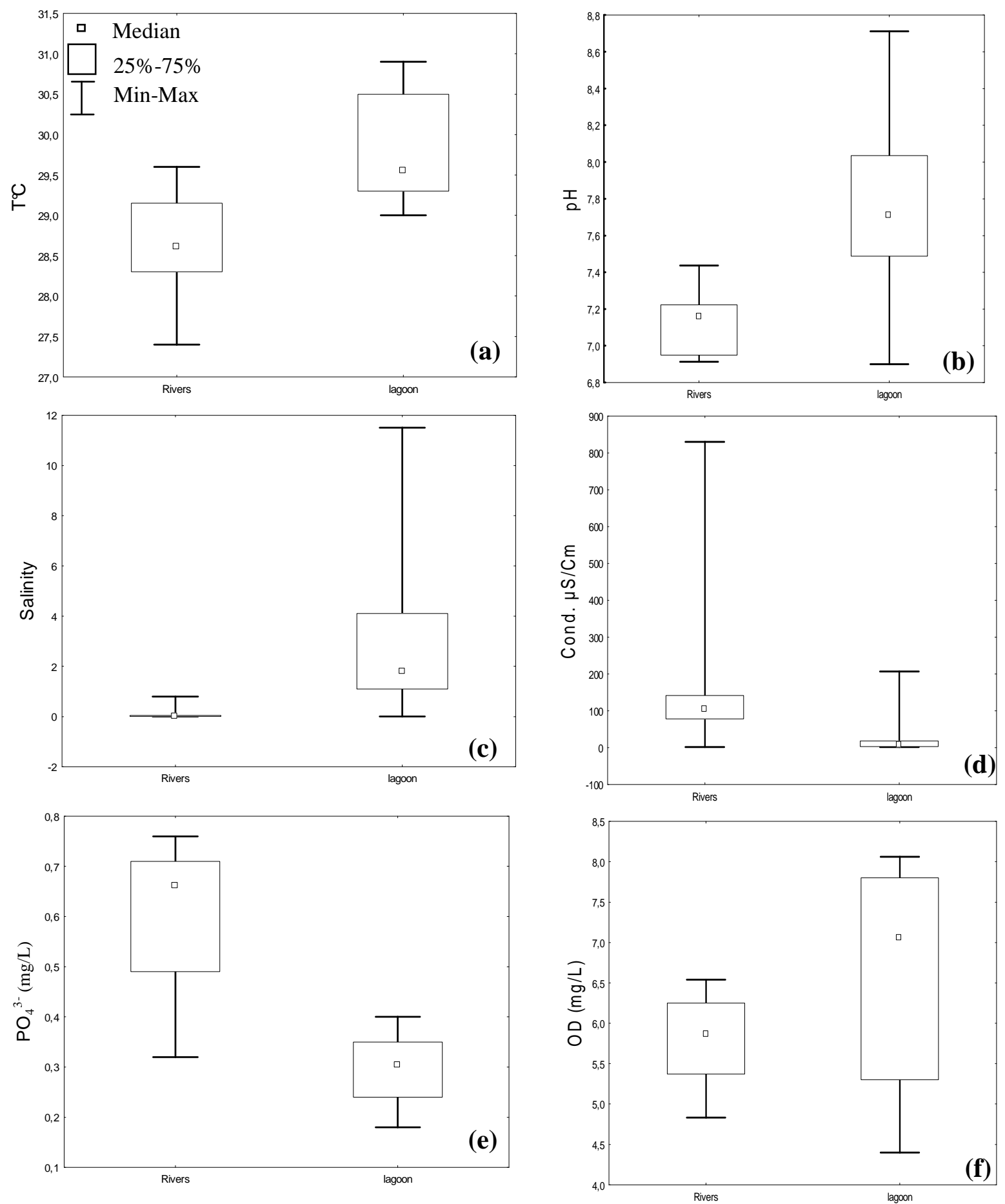

Figure 4: Statistical comparison of physicochemical parameters of Lagoon and Rivers and box plot of (a) temperature, (b) $\mathrm{pH}$, (c) salinity, (d) conductivity, (e) $\mathrm{PO}_{4}{ }^{3-}$ and (f) dissolved oxygen in wet season. 

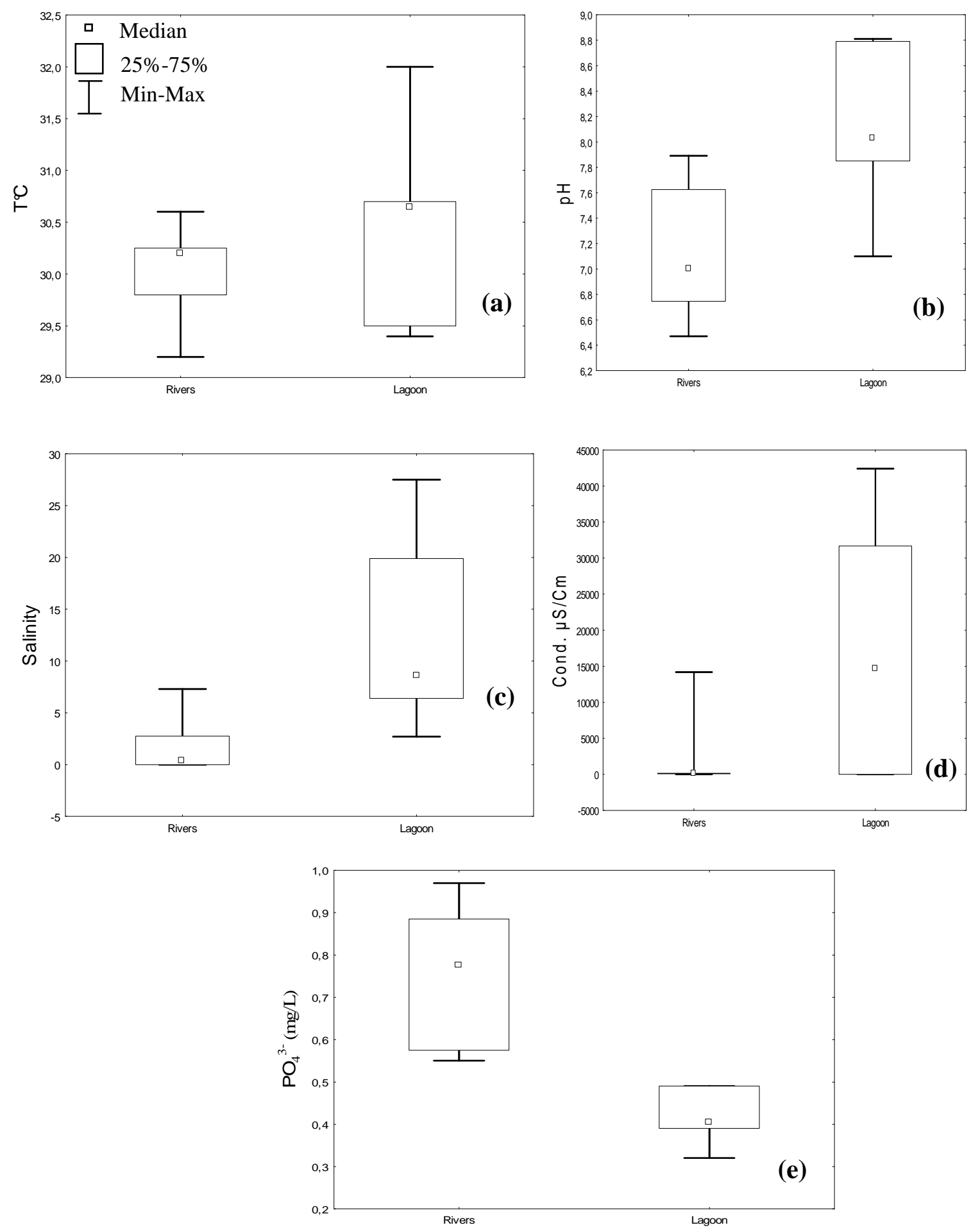

Figure 5: Statistical comparison of physico-chemical parameters of Lagoon and Rivers and box plot of (a) temperature, (b) $\mathrm{pH}$, (c) salinity, (d) conductivity and (e) $\mathrm{PO}_{4}{ }^{3-}$ in dry season. 
Table 1: Summary of physico-chemical parameters of water of the study sites (Côte d'Ivoire lagoonal system) in wet season.

\begin{tabular}{|c|c|c|c|c|c|c|}
\hline \multirow[t]{2}{*}{ Parameters } & \multicolumn{3}{|c|}{ Rivers } & \multicolumn{3}{|c|}{ Lagoons } \\
\hline & $\max$. & min. & Mean \pm SD & max. & min. & Mean \pm SD \\
\hline $\mathrm{T}^{\circ} \mathrm{C}$ & 29.60 & 27.40 & $28.64 \pm 0.67$ & 30.90 & 29.00 & $29.80 \pm 0.70$ \\
\hline $\mathrm{pH}$ & 7.44 & 6.91 & $7.13 \pm 0.17$ & 8.71 & 6.90 & $7.76 \pm 0.57$ \\
\hline Salinity & 0.80 & 0.00 & $0.11 \pm 0.27$ & 11.50 & 0.00 & $3.38 \pm 3.90$ \\
\hline Cond. $(\mu \mathrm{S} / \mathrm{cm})$ & 830.00 & 2.27 & $184.62 \pm 250.81$ & 207.00 & 2.26 & $40.38 \pm 75.99$ \\
\hline $\mathrm{PO}_{4}-\mathrm{P}(\mathrm{mg} / \mathrm{L})$ & 0.97 & 0.55 & $0.75 \pm 0.16$ & 0.49 & 0.32 & $0.42 \pm 0.06$ \\
\hline DO (mg/L) & 6.54 & 4.83 & $5.79 \pm 0.57$ & 8.06 & 4.40 & $6.61 \pm 1.36$ \\
\hline $\mathrm{NH}_{4}-\mathrm{N}(\mathrm{mg} / \mathrm{L})$ & 0.70 & 0.12 & $0.47 \pm 0.21$ & 0.82 & 0.26 & $0.57 \pm 0.179$ \\
\hline $\mathrm{NO}_{3}-\mathrm{N}(\mathrm{mg} / \mathrm{L})$ & 1.75 & 0.25 & $0.88 \pm 0.45$ & 1.90 & 0.71 & $1.18 \pm 0.45$ \\
\hline $\mathrm{NO}_{2}-\mathrm{N}(\mathrm{mg} / \mathrm{L})$ & 0.22 & 0.09 & $0.15 \pm 0.04$ & 0.20 & 0.10 & $0.15 \pm 0.04$ \\
\hline
\end{tabular}

Table 2: Summary of physico-chemical parameters of water of the study sites (Côte d'Ivoire lagoonal system) system in dry season

\begin{tabular}{|c|c|c|c|c|c|c|}
\hline \multirow[t]{2}{*}{ Parameters } & \multicolumn{3}{|c|}{ Rivers } & \multicolumn{3}{|c|}{ Lagoons } \\
\hline & max. & min. & Mean \pm SD & max. & min. & Mean \pm SD \\
\hline $\mathrm{T}^{\circ} \mathrm{C}$ & 30,60 & 29.20 & $30.04 \pm 0.41$ & 32.00 & 29.40 & $30.48 \pm 0.89$ \\
\hline $\mathrm{pH}$ & 7.89 & 6.47 & $7.14 \pm 0.50$ & 8.81 & 7.10 & $8.10 \pm 0.60$ \\
\hline Salinity & 7.30 & 0.00 & $1.70 \pm 2.44$ & 27.50 & 2.70 & $12.30 \pm 8.83$ \\
\hline $\begin{array}{l}\text { Cond. } \\
(\mu \mathrm{S} / \mathrm{cm})\end{array}$ & $\begin{array}{c}14160 . \\
00\end{array}$ & 4.36 & $1856.81 \pm 4709.67$ & 42400.00 & 5.02 & $\begin{array}{c}17214.36 \pm 15946.8 \\
0\end{array}$ \\
\hline $\begin{array}{l}\mathrm{PO}_{4}-\mathrm{P} \\
(\mathrm{mg} / \mathrm{L})\end{array}$ & 0.76 & 0.32 & $0.60 \pm 0.14$ & 0.40 & 0.18 & $0.30 \pm 0.072$ \\
\hline DO (mg/L) & 7.01 & 4.90 & $6.02 \pm 0.74$ & 6.70 & 4.62 & $5.84 \pm 0.75$ \\
\hline $\begin{array}{l}\mathrm{NH}_{4}-\mathrm{N} \\
(\mathrm{mg} / \mathrm{L})\end{array}$ & 0.82 & 0.20 & $0.59 \pm 0.22$ & 0.92 & 0.47 & $0.69 \pm 0.15$ \\
\hline $\begin{array}{l}\mathrm{NO}_{3}-\mathrm{N} \\
(\mathrm{mg} / \mathrm{L})\end{array}$ & 1.91 & 0.18 & $0.87 \pm 0.50$ & 1.52 & 0.66 & $1.11 \pm 0.30$ \\
\hline $\begin{array}{l}\mathrm{NO}_{2}-\mathrm{N} \\
(\mathrm{mg} / \mathrm{L})\end{array}$ & 0.25 & 0.06 & $0.14 \pm 0.06$ & 0.23 & 0.08 & $0.15 \pm 0.06$ \\
\hline
\end{tabular}

Tabulated values are Mean \pm SD of 40 determinations for Rivers and 30 determinations for Lagoons ; ANOVA test at $\mathrm{P}<0.05$.

$\mathrm{T}^{\circ} \mathrm{C}$, temperature; Cond., conductivity; $\mathrm{PO}_{4}-\mathrm{P}$, phosphate-phosphorus; $\mathrm{DO}$, dissolved oxygen; $\mathrm{NH}_{4}-\mathrm{N}$, ammonia-nitrogen; $\mathrm{NO}_{3}-\mathrm{N}$, nitrate-nitrogen; $\mathrm{NO}_{2}-\mathrm{N}$, nitrite-nitrogen; $\mathrm{SD}$, standard deviation. 

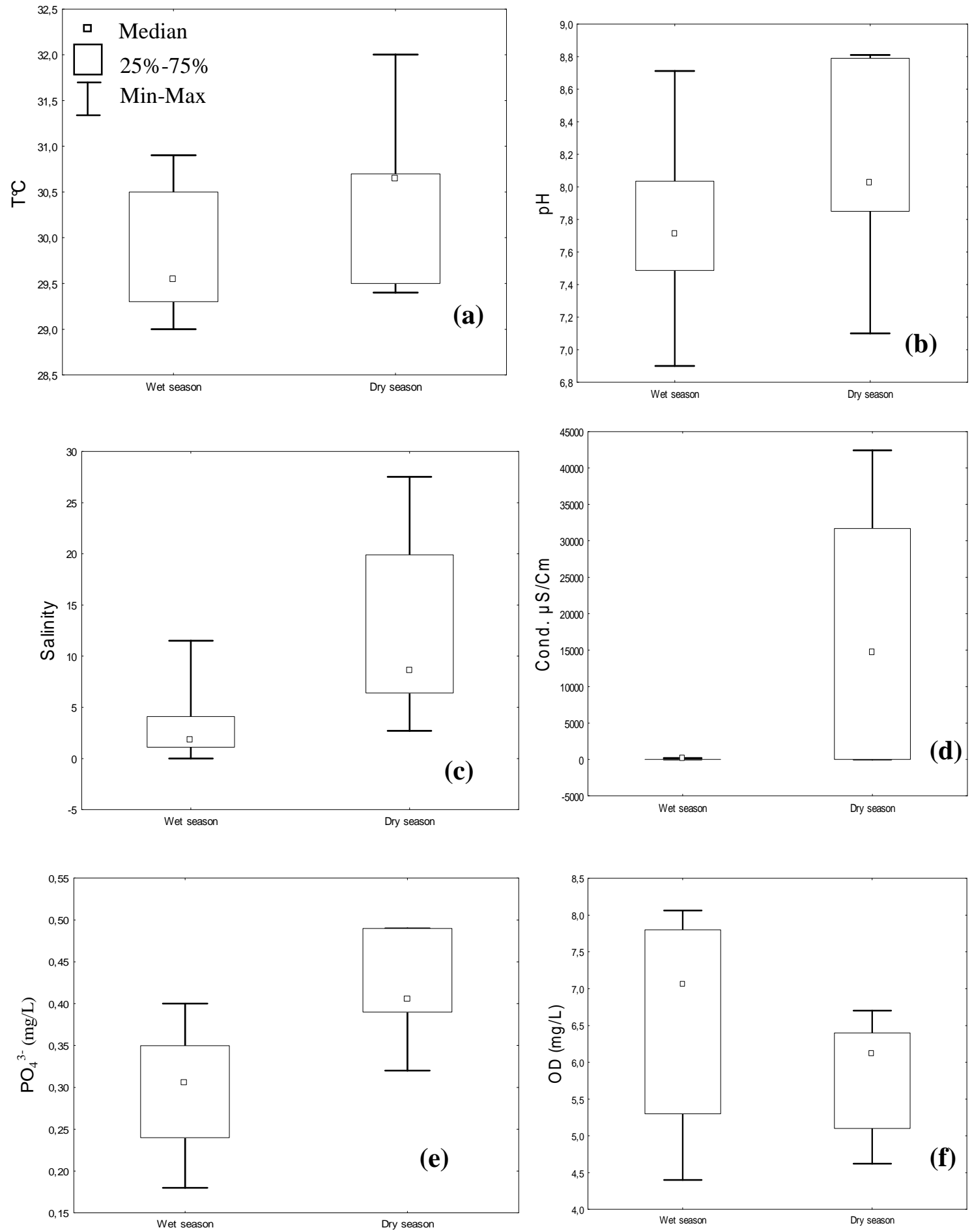

Figure 6: Statistical comparison of physicochemical parameters of wet season and dry season and box plot of (a) temperature, (b) $\mathrm{pH}$, (c) salinity, (d) conductivity, (e) $\mathrm{PO}_{4}{ }^{3-}$ and (f) dissolved oxygen in Lagoons. 
seasons, $\mathrm{NO}_{3}-\mathrm{N}$ and $\mathrm{NO}_{2}-\mathrm{N}$ concentrations did not show a seasonal variability and values were constant.

The comparison of physico-chemical parameters of the study area shows that temperature, $\mathrm{pH}$, salinity, conductivity and phosphate-phosphorus values were higher during the dry season than in wet season in Lagoons (Figure 6). While, dissolved oxygen values were lower in dry season than in wet season in the same zone. Figure 7 shows that only temperature, salinity and phosphorus were higher in dry season than in wet season in rivers.

\section{Phosphorus content of water hyacinth}

Table 3 shows phosphorus contents of water hyacinth collected from the rivers and lagoons during the two seasons. The concentration of phosphorus in water hyacinth varied slightly from the wet season to the dry season. Average values ranged from $3.7 \mathrm{mg} / \mathrm{g}$ to $4.3 \mathrm{mg} / \mathrm{g}$ with the highest observed during the dry season in rivers. The same pattern was observed in the lagoons and average values ranged from $3.6 \mathrm{mg} / \mathrm{g}$ to $4.6 \mathrm{mg} / \mathrm{g}$ with the lowest values obtained during the wet season. The concentrations of phosphorus in the different organs of water hyacinth showed that rhizomes accumulate more phosphorus (5.0 $\mathrm{mg} / \mathrm{g}$ ) during the wet season than leaves and roots in the rivers. In contrast, during the same season, rhizomes accumulate less phosphorus $(3.01 \mathrm{mg} / \mathrm{g}$ ) water hyacinth organs depended on the seasons. ANOVA test showed that differences between concentrations of phosphorus in water hyacinth bodies were significant, although there was no correlation between total-phosphorus content of water hyacinth and rivers and lagoons phosphorus concentration.

\section{DISCUSSION}

Higher pH values inhibit Eichhornia crassipes growth (Trinidad et al., 2008) and can contribute to the disappearance of these floating macrophytes in the lagoons during the dry season when oceanic water influence is maximal. However, its role in the distribution of these floating macrophytes in lagoons of Côte d'Ivoire seems to be minor in comparison to other factors such as salinity and river water discharges. Thus, the disappearance of Eichhornia crassipes in the eastern part of Ebrié was due to the low water discharge from Comoé and La Mé rivers and to the increase of salinity related to the strong inputs of sea water. In the case of Aby lagoon, the absence of floating macrophytes in this system was related to the fact that maximal proliferation of Eichhornia crassipes is coupled with low freshwater discharge particularly in Tanoé River. Moreover, water current dynamics and a relatively constant salinity in Aby lagoon system probably preclude the establishment of floating macrophytes. Whatever the season, $\mathrm{pH}$ values in the rivers were lower than those in the lagoons due to the fact that these rivers are currently oversaturated in $\mathrm{CO}_{2}$ with respect to the atmosphere (Koné et al., 2009). Indeed, higher $\mathrm{CO}_{2}$ concentrations in aquatics systems decrease $\mathrm{pH}$ values. In contrast, the highest $\mathrm{pH}$ values found in lagoons particularly in Aby lagoon was related to primary production that uptakes atmospheric $\mathrm{CO}_{2}$ and thus, increases pH values (Koné et al., 2009). Temperature is another factor that controls the distribution of Eichhornia crassipes in freshwater and lagoons. However, although average temperature values found in rivers and lagoons of Côte d'Ivoire were higher (25 ${ }^{\circ} \mathrm{C}$ and $\left.27^{\circ} \mathrm{C}\right)$, they were below the mean value $\left(40{ }^{\circ} \mathrm{C}\right)$ that is expected to inhibit Eichhornia crassipes growth (Trinidad et al., 2008). The significant difference between temperature values found in rivers and lagoons was related to the fact that the former aquatic systems are bordered by trees which 

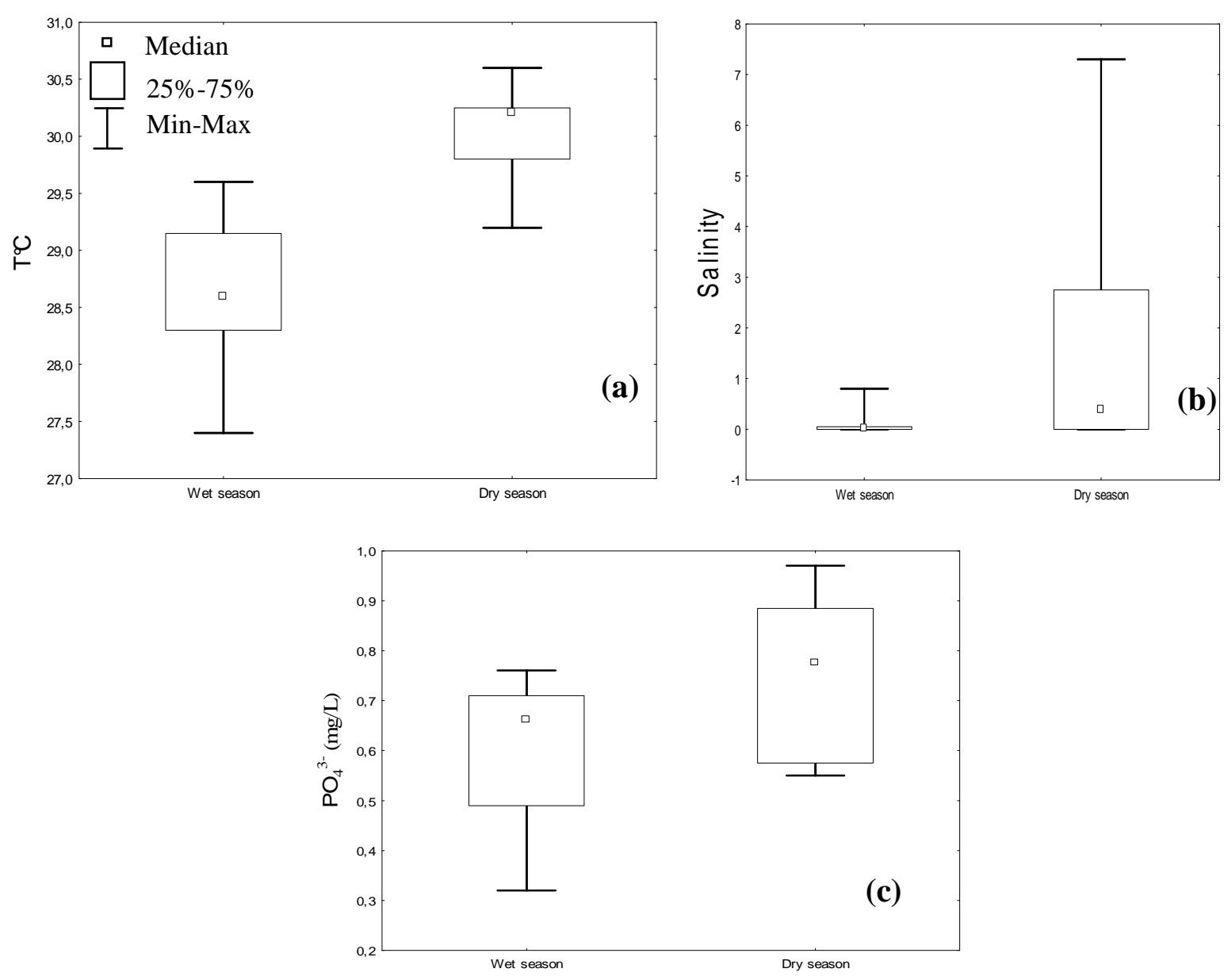

Figure 7: Statistical comparison of physico-chemical parameters of wet season and dry season and box plot of (a) temperature, (b) salinity and (c) $\mathrm{PO}_{4}{ }^{3-}$ in rivers.

Table 3: Total-phosphorus content of Eichhornia crassipes (mg/g of dry matter)

\begin{tabular}{cccccc}
\hline \multirow{2}{*}{ Plants organs } & \multicolumn{2}{c}{ Wet season } & \multicolumn{2}{c}{ Dry season } \\
\cline { 2 - 5 } & & Rivers & Lagoons & Rivers & Lagoons \\
\hline \multirow{2}{*}{ Leaves } & Maximum & 8.10 & 10.05 & 8.66 & 8.97 \\
& Minimum & 0.20 & 1.58 & 2.45 & 2.94 \\
& Mean \pm SD & $3.66 \pm 0.24$ & $4.14 \pm 0.37$ & $4.36 \pm 0.23$ & $5.31 \pm 0.45$ \\
\multirow{2}{*}{ Roots } & Maximum & 6.36 & 7.13 & 6.85 & 7.07 \\
& Minimum & 0.96 & 1.23 & 2.79 & 3.55 \\
\multirow{5}{*}{ Rhizomes } & Mean \pm SD & $3.16 \pm 0.17$ & $3.56 \pm 0.24$ & $4.56 \pm 0.16$ & $5.03 \pm 0.30$ \\
& Maximum & 7.79 & 6.34 & 9.68 & 6.06 \\
& Minimum & 0.66 & 1.00 & 1.88 & 1.82 \\
& Mean \pm SD & $4.97 \pm 0.30$ & $3.01 \pm 0.24$ & $3.90 \pm 0.28$ & $3.40 \pm 0.33$ \\
\hline
\end{tabular}

Tabulated values are Mean \pm SD of 70 determinations for wet season and 55 determinations for dry season; ANOVA test at $\mathrm{P}<0.05$. 
canopy decreases temperature values in water column.

The lowest nutrient concentrations found in rivers and lagoons of Côte d'Ivoire are consistent with those reported by Akpavi et al. (2005) in the Eastern coastal area of Togo, where Eichhornia crassipes develops well in any season. These lowest nutrient concentrations in lagoons and rivers were due to the fact that Eichhornia crassipes store them during its nutrition. The significant difference between nutrient concentrations in rivers and lagoons was related to its diffuse sources from land leaching. When the higher concentrations of rivers were discharged into lagoons, they are diluted by oceanic water, normally very low in nutrients such as phosphorus and nitrogen (Ramade, 1995). Phosphorus contents in the three parts of Eichhornia crassipes were different and related to the aquatic systems. These results suggest that in the higher phosphorus conditions (like rivers), Eichhornia crassipes accumulates more phosphorus in the rhizomes than in the other parts. By contrast, in the lower phosphorus conditions (like lagoons), Eichhornia crassipes accumulates more phosphorus in the leaves than in the other parts. However, our data are insufficient to elucidate the reasons that promote this difference uptake of phosphorus in the different parts of Eichhornia crassipes in aquatic systems. Thus, further investigations are needed to better understand these different uptakes of phosphorus in the three parts of Eichhornia crassipes.

\section{ACKNOWLEDGMENTS}

The authors would like to acknowledge Laboratory of Environment and Aquatic Biology (University of AboboAdjame) for its assistance in sampling. We also thank Koné Y.J.M. and K.N. Kouadio for their assistance during the fieldwork and their remarkable criticisms. We also thank two anonymous persons who helped us to prepare the present manuscript.

\section{REFERENCES}

AFNOR. 2001. Quality of Water, Main Elements, other Elements and Mineral Composites (Vol. 3, 6th edn). Afnor: Paris.

Akpavi S, Batawita K, Djaneye-Boundjou G, Afidegnon D, De Foucault B, Akpagana K, Bouchet P. 2005. A contribution to the knowledge of Eichhornia crassipes (Mart.) Solms-Laub. (Pontederiaceae) and Pistia stratiotes L. (Araceae) ecology in the Eastern maritime Togo. Acta Bot. Gallica, 152 (3): 269-280.

Almoustapha O, Millogo-Rasolodimby J, Kenfack S. 2008. Production of biogas and compost starting from the water hyacinth for Sustainable development in Sahelian Africa. VertigO - Review in Sciences of the Environment, 8 (1): 1-8

Barrett SCH, Forno IW. 1982. Style morph distribution in New World populations of Eichhornia crassipes (Mart) SolmsLaubach (water hyacinth). Aquatic Botany, 13: 299-306.

Binet D, Le Reste L, Diouf PS. 1995. The influence of runoff and fluvial outflow on the ecosystems and living resources of West African coastal waters. In Effects of riverine impacts on coastal ecosystems and fisheries, FAO, 89-117.

Center TD, Pratt PD, Rayamajhi MB, Van TK, Franks SJ, Dray FAJ, Rebelo MT. 2005. Herbivory alters competitive interactions between two invasive aquatic plants. Biol. Control, 33(2): 173185.

Dufour P. 1982. Natural and human boundaries of Ebrié lagoonal system. Incidences on the hydroclimate. Hydrobiologia, 94: 105-120.

Durand JR, Chantraine JM. 1982. Climatic environment of the lagoons of Côte 
d'Ivoire. Rev. Hydrobiol. Trop., 15(2): 85-113.

Ghabbour EA, Davies D, Lam YY, Vozzella ME. 2004. Metal binding by humic acids isolated from water hyacinth plants (Eichhornia crassipes [Mart.] SolmLaubach: Pontederiaceae) in the Nile Delta, Egypt. Environ. Pollut., 131: 445451.

Jayaweera MW, Dilhani JAT, Kularatne RKA, Wijeyekoon SLJ. 2007. Biogas production from water hyacinth (Eichhornia crassipes (Mart.) Solms) grown under different nitrogen concentrations. Journal of Environmental Science and Health, Part A, 42: 925-932.

Jayaweera MW, Kasturiarachchi JC. 2004. Removal of nitrogen and phosphorus from industrial wastewaters by phytoremediation using water hyacinth (Eichhornia crassipes (Mart.) Solms). Water Sci. Technol., 50: 217-225.

Koné YJM, Abril G, Kouadio KN, Delille B. Borges AV. 2009. Seasonal Variability of Carbon Dioxide in the Rivers and Lagoons of Ivory Coast (West Africa). Estuaries and Coasts, 32: 246-260.

Kumar S. 2005. Studies on efficiencies of biogas production in anaerobic digesters using water hyacinth and night-soil alone as well as in combination. Asian J. Chem., 17: 934-8.
Masifwa WF, Okello W, Ochieng H, Ganda E. 2004. Phosphorus release from decomposing water hyacinth and effects of decomposition on water quality. Uganda Journal of Agricultural Sciences, 9: 389-395.

Polprasert C, Kongsrichaern N, Kanjanaprapin W. 1994. Production of feed and ferliser from water hyacinth plants in the tropics. Waste Management and Research, 12: 3-11.

Ramade F. 1995. Elements of Ecology Ecology Applied Human Action on the Biosphere (5th edn). Ediscience International.

Soltan ME, Rashed MN. 2003. Laboratory study on the survival of water hyacinth under several conditions of heavy metal concentrations. Adv. Environ. Res., 7(2): 82-91.

Statsoft, 2005. Statistica (data analysis software system). Version 7.1. Tulsa, OK, USA.

Trinidad RT, Elsa MRL, Gloria LG, Eva AP, Ricardo ML, Juan MSG. 2008. The Water. Aquatic Invasions, 3(1): 42-53.

Woomer PL, Muzira R, Bwamiki D, Mutetikka D, Amoding A, Bekunda MA. 2000. Biological management of water hyacinth waste in Uganda. Biol. Agri. Hortic., 17: 181-96. 